\section{The Shroud of Turin}

SIR-Both the scientists involved and outside observers such as myself have been astonished at the recent decision of the Archbishop of Turin, Anastasio Ballestrero, to withdraw from four of the seven participating laboratories permission to carbon-test the Shroud of Turin.

This action, supposedly made in the interests of conservation of the shroud linen, leaves in a shambles the carefully devised plans of the group of experts who met in the autumn of 1986 to draw up testing procedures for the cloth. As things now stand, only laboratories at the University of Arizona, the Technical University in Zurich and the University of Oxford will be given shroud samples. Shut out from the tests will be Dr Harry Gove of the University of Rochester and Dr Garman Harbottle of the Brookhaven National Laboratory, as well as the Saclay Laboratory in France and the Atomic Energy Research Authority in Harwell.

Of equal importance is the fact that the Vatican officials in charge of the test have still not come forward with procedures to secure the authenticity of the samples themselves - procedures, for example, to make it impossible for ancient mummy linen to be surreptitiously introduced into the chain of evidence. If the shroud linen is itself of ancient origin, but the tested samples are not provably from the shroud, then there will be no reason for anybody to take the test results seriously.

I call on all the concerned laboratories to withdraw from the tests until such time as the Vatican decides to go back to the seven-laboratory plan, with strict, open procedures to ensure the authenticity of samples.

School of Fine Arts,

Denis Dutton

University of Canterbury,

Christchurch, New Zealand

SIR-Those in a position to apply scientific tests to the Shroud of Turin might care to look for asbestos fibres in it, as well as in the other folds of the shroud reported (by Murray's Guide to Northern Italy, 1883) to exist in Rome, Besançon and Cadouin.

Marco Polo, after describing the extraction of asbestos in China, from mines perhaps near Hami in Sinkiang, says that the fibres, which look like wool, are spun into napkins which may be cleaned by being put into the fire. He continues: "And I will also tell you that in Rome there is a napkin that the Great Kaan sent to the Pope as a splendid present, when he sent the two Polo brothers [Niccolo, Marco's father and Matteo his uncle] to him as envoys, in order that the sacred shroud of Our Lord Jesus Christ might be wrapped up in it. And on that napkin are golden letters, saying Tu es Petrus et super hanc petram edificabo ecclesiam meam" (Travels of Marco Polo, Routledge \& Kegan Paul, 1931, p.74).

In fact, in 1269, when the Polo brothers arrived back with this present from Kublai Khan, it was in a period (1268-71) when there was no Pope. The Shroud of Turin, apparently, was not reported before the fourteenth century, but we may wonder whatever happened to the fireproof cover, especially as some have considered that the shroud carries scorch marks.

Alan L. MaCKay

Department of Crystallography,

Birkbeck College,

Malet Street, London WC1E 7HX, UK

\section{Independent Estonia}

SIR-Contrary to the statement in your article "The Finn red line" (Nature 330, $331 ; 1987)$, Estonia was not part of Finland before the Second World War but was an independent republic in its own right.

Who's rewriting history now?!

T. OJasoo

17 York Road,

Stafford ST17 4PE, UK

\section{Moral failure?}

SIR-Why is the AIDS pandemic accompanied by paralysis of the faculty of logical reasoning as none other? The leading article "Whose own goal?" (Nature 331, $376 ; 1988$ ) is a case in point. It concludes "AIDS is not a moral failure but a viral infection". Why should the two be mutually exclusive?

For the sake of argument let us consider that there is an epidemic of red noses. Let us first suppose that red noses are caused by the transmission of a virus from one individual to another by, say, rubbing noses. Second, let us suppose that this is more likely to happen when males rub noses (homonasal contact) in Europe, but far more readily transmitted by heteronasal contact in Africa. Transmission by blood is unfortunately also becoming more frequent. What public health measures need to be instituted to contain the pandemic? First, nose rubbing needs to be avoided except with one partner not infected with the virus. This is the "no-risk option'. Secondly, and a flawed alternative, noses must be protected during multiple contacts. This is a 'lower-risk option'. Blood transmission needs to be dealt with separately.

In this scenario, alteration in human conduct is necessary for the greater good of all. One of the Oxford English Dictionary's definitions of morality is "principles dealing with regulation of conduct". Prevention of infected nose rubbing is, there- fore, to do with morality and public health.

Thus it is with AIDS - a viral pandemic produced by patterns of human behaviour which deviate from a fundamental code of moral behaviour. The further tragedy is that innocent parties are becoming increasingly and lethally vulnerable.

The Princes's Royal was absolutely correct in what she said. AIDS is indeed "mankind's own goal" - a viral infection turned into a pandemic by moral failure

University of Bristol, Gordon M. StirRat

Department of Obstetrics

and Gynaecology,

Bristol Maternity Hospital,

Southwell Street, Bristol BS2 8EG, UK

\section{Arabs and Israelis}

SIR-I was extremely surprised by Nechemia Meyers' article entitled "ArabIsraeli cooperation goes public" (Nature 330, 302; 1987).

I have never been involved in any "cooperative science project" with Israeli researchers. My only contacts with researchers from Israel have been seminars or scientific meetings organized by the French Cancer Research Association (ARC) or international organizations such as the UICC or WHO. The second day of a twoday ARC-sponsored French-Mediterranean colloquium, on 17 November 1987 , was used for the presentation of the "Preliminary Results of the TunisianFrench Research Project on Inflammatory Breast Cancer". As the person responsible for this project, I was asked to be moderator of the one-day discussion on inflammatory breast cancer. Dr Feldman, on the other hand, was responsible for the organization of the other day, which treated a subject with absolutely no relation to mine. It is therefore difficult to see how, from such superficial contact, "the potential for collaboration between Arab and Israeli researchers" could be considered as "evident".

Let me conclude by saying that I am not only a government officer, but am also in total support of the position held by my government: I believe that the most important question at the present time is not scientific cooperation, but the search for a political solution to the Palestinian problem.

Institut Salah Azaiz,

Nejib Mourali

Bab Saadoun,

Tunis,

Tunisia

Nechemia Meyers adds: I had not intended to imply that Professor Mourali had been involved in a cooperative research project but only that there is potential for collaboration that will materialize only, as I quoted Professor Feldman as saying, if "politicians get their act together". 